\title{
ANALISIS PERBANDINGAN MINAT BERWIRAUSAHA DAN BEKERJA SEBAGAI KARYAWAN DI MASA PANDEMI COVID-19 (Studi Kasus Mahasiswa Prodi Manajemen UIN Sunan Ampel Surabaya)
}

\author{
Anisa Yusrin Nanda ${ }^{1}$, Muchammad Saifuddin ${ }^{2}$ \\ ${ }^{1}$ Program Studi Manajemen, UIN Sunan Ampel Surabaya \\ email: anisayusrinn@gmail.com \\ ${ }^{2}$ Program Studi Manajemen, UIN Sunan Ampel Surabaya \\ email: saifuddin@uinsby.ac.id
}

\begin{abstract}
. The Covid-19 pandemic not only affects the health sector, but also the economic sector. Many workers are threatened by the impact of the Covid-19 pandemic. Likewise with entrepreneurs, who experience losses due to social distancing that limit the space for business actors. This research was conducted with the aim of looking at the comparison between interest of entrepreneurship and working as an employee during the Covid-19 pandemic. This research uses a descriptive qualitative method. Based on the sampling technique using the purposive sampling method, then obtained 26 respondents. Data gathering techniques are conducted through interviews with sources. Data analysis using the Miles and Huberman model data analysis. Research results show that the interest of entrepreurship during the pandemic is higher than that interest of employees. Interest in entrepreneurship is superior, namely 17 respondents, while the remaining 9 respondents are interested in working as employees during the Covid19 pandemic.
\end{abstract}

Keywords: Entrepreneurship, Employees, Pandemic Covid-19

\section{PENDAHULUAN}

Suatu hal menjadi kekahwatiran saat ini adalah bahwa Indonesia tengah menghadapi masalah yang kompleks yaitu sulitnya para alumni dari berbagai perguruan tinggi untuk bekerja serta banyaknya pengangguran. Menurut data Badan Statistika Pusat, terhitung sampai bulan Agustus 2020 jumlah pengangguan di Indonesia sebanyak 2,56 juta orang [1].

Di masa pandemi Covid-10 ini, karyawan perusahaan atau pabrik-pabrik mengalami PHK (Pemutusan Hubungan Kerja) dan dirumahkan sampai dengan waktu yang belum pasti kapan berakhir. Sampai saat ini, para pekerja yang terpaksa dirumahkan sementara pun masih ragu apakah akan tetap bekerja atau tidak.

Pandemi COVID-19 ini juga berdampak pada sektor UMKM. Saat ini sebanyak 1.785 koperasi dan 163.713 pelaku usaha mikro yang terkena dampak pandemi covid-19. Kebanyakan koperasi yang terkena dampak Covid-19 bergerak pada bidang kebutuhan sehari-hari, sedangkan sektor UMKM yang paling terdampak yakni makanan dan minuman. Pengelola Koperasi mengalami kesulitan modal dan distribusi sehingga penjualan mereka menurun. Sementara itu, Pelaku UMKM juga mengalami hal yang serupa. Pandemi ini telah membuat industri rumahan, kreatif dan pertanian juga terkedan dampak besar. Kemenkop UMKM menerima laporan bahwa ada sekitar 37.000 UMKM yang terdampak sangat serius dengan adanya pandemi ini. 56 persen mengalami penurunan penjualan, 22 persen mengalami permasalahan pada aspek pembiayaan, 15 persen menghadapi masalah distribusi barang, dan 4 
persen mengalami kesulitan mendapatkan bahan baku mentah. [2]

Dengan begitu, salah satu masalah mendasar yang dihadapi oleh perguruan tinggi adalah masalah relevansi dan mutu yang belum menggembirakan. Saat ini Pendidikan tinggi belum sepenuhnya mampu melahirkan enterpreneur dengan orientasi job creating dan kemandirian [3]. Alumni yang merupakan pengangguran terdidik terus bertambah, problem pengabdian masyarakat dimana perguruan tinggi tersebut dirasa kurang responsif, dan berkontribusi terhadap problematika masyarakat.

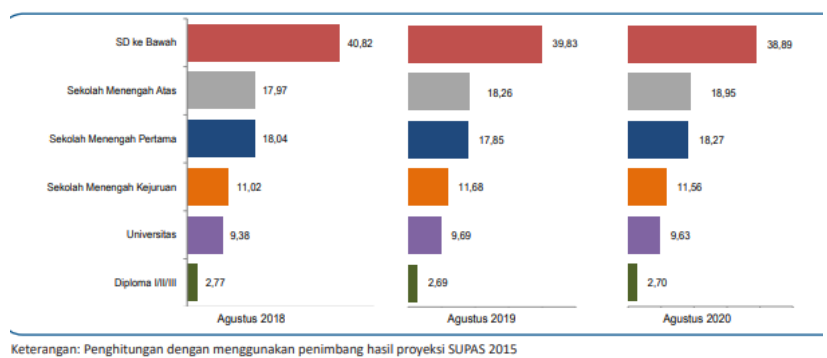

Gambar 1.1 Persentase Penduduk Bekerja Menurut Pendidikan Tertinggi yang Ditamatkan Agustus 2018Agustus 2020

Pada Agustus 2020, penduduk bekerja masih didominasi oleh mereka yang berpendidikan SD ke bawah. Sementara tenaga kerja yang berpendidikan tinggi, yaitu Diploma dan Universitas menduduki peringkat paling bawah [1].

Menjadi pengusaha maupun karyawan merupakan sebuah profesi yang paling diminati para lulusan perguruan tinggi. Berwirausaha merupakan suatu kegiatan menciptakan usaha atau memulai suatu usaha. Kewirausahaan dikatakan sangat penting karena dapat meningkatkan pertumbuhan ekonomi secara umum di suatu negara. Salah satu usaha yang paling tepat untuk menanggulagi masalah pengangguran saat ini adalah berwirausaha. Begitu juga menjadi karyawan, instansi atau perusahaan dapat berkembang jika terdapat karyawan-karyawan yang berpotensi untuk mengembangkan sebuah perusahaannya.
Bedasarkan masalah yang telah dipaparkan diatas, peneliti ingin mengetahui perbandingan antara mahasiswa yang minat berwirausaha dan bekerja sebagai karyawan dimasa Pandemi Covid'19. Tujuan penelitian ini dilakukan untuk mengetahui perbandingan minat berwirausaha dan bekerja sebagai karyawan di masa pandemic Covid-19.

\section{Kewirausahaan}

Pada awal-awal kewirausahaan dikenalkan kepada masyarakat dan dunia dalam pendidikan. Terdapat pandangan yang berbedabeda tentang kewirausahaan ini, antara lain:

a. Kewirausahaan adalah ilmu pengetahuan. Karena kewirausahaan merupakan sebuah hasil uji di lapangan, dikumpulkan, diteliti, dan diranngkai sebagai sumber informasi yang berguna bagi orang lain yang membutuhkannya.

b. Kewirausahaan adalah suatu bentuk kepribadian atau sikap, karena unsur yang ada didalam diri jiwa wirausaha adalah skap positif, kepribadian yang ulet, pantang menyerah dan tidak mudah puas diri.

c. Kewirausahaan adalah skill, karena kewirausahaan merupakan penggabungan dua konsep penting yaitu pengetahuan dan pengalaman yang dirasakan serta dilakukan melaului jatuh-bangun untuk menjadi terampil dan akhirnya menjadi sebuah keahliam dalam menjalankan roda bisnis.

d. Kewirausahaan adalah sebuah profesi. Menjadi wirausaha merupakan sebuah profesi sebagai pilihan hidup. Karena dengan menjadi wirausaha, seseorang akan menciptakan lapangan kerja [4].

Dari beberapa pengertian diatas dapat diambil kesimpulan bahwa kewirausahaan adalah kemampuan seseorang untuk menciptakan sesuatu yang baru dan berbeda dari yang telah ada dengan tujuan untuk mencapai kemakmuran melalui penciptaan peluang.

\section{Pekerja/Karyawan}


Tenaga kerja baik berupa pekerja atau karyawan, merupakan penggerak organisasi dalam mewujudkan eksistensinya atau potensi yang merupakan aset dan berfungsi sebagai modal non material dalam organisasi bisnis yang dapat diwujudkan menjadi potensi nyata secara fisik dan non fisik dalam mewujudkan eksistensi organisasi (Nawawi, 2011). Karyawan adalah setiap orang yang menjual tenaganya (fisik dan pikiran) kepada perusahaan dimana dia bekerja dengan terikat perjanjian ubah atau gaji. [5].

\section{Minat Berwirausaha}

Minat merupakan kecenderungan atau kegairahan yang tinggi terhadap sesuatu. Minat menjadi wirausaha dapat diartikan sebagai keinginan seseorang untuk bekerja mandiri (selfemployed) atau menjalankan usahanya sendiri. Budiati, Yani, dan Universari (2012) dalam penelitian menyatakan bahwa minat mahasiswa menjadi wirausaha dibagi dalam empat kelompok yaitu: 1) Minat wirausahan yang memulainya dalam waktu dekat. 2) Minat memulai wirausaha dua tahun mendatang 3) Minatmemulai wirausaha untuk jangka panjang, dan 4) Tidak berminat untuk berwirausaha [6].

Indikator minat berwirausaha merujuk pada pendapat Iskandar (2001) adalah ketertarikan seseorang atau sekelompok oang untuk berwirausaha, bersedia terlibat dalam kegiatan kewirausahaan, melihat adanya peluang untuk berwirausaha, mau berwirausahan dengan memanfaatkan potensi yang dimiliki, berani menghadapi resiko, tantangan, senang terhadap kegiatan kewirausahaan, berkeinginan untuk mewujudkan impiannya memili usaha [7]. Minat berwirausaha juga dapat dikatakan sebagai kecenderungan seseorang untuk menjalankan bisnis/usaha.

\section{Minat Bekerja Sebagai Karyawan}

Pilihan pekerjaan merupakan suatu tindakan ekspresif yang merupakan refleksi dari motivasi, pengetahuan, kepribadian, dan kemampuan individu. Melalui pemahaman yang benar akan pekerjaan yang sesuai bagi diri individu, maka akan dapat dipilih jenis pekerjaan tertentu yang sesuai dengan harapan dan potensi yang dimiliki individu tersebut (Spokane, 1996). Minat bekerja sebagai karyawan merupakan sebuah keinginan atau ketertarikan terhadap pekerjaan yang diawali dari upaya pencarian informasi tentang lowongan pekerjaan, berdasarkan informasi-informasi tersebut, calon karyawan diarahkan untuk mengambil keputusan tentang perusahaan tujuan mereka [8].

\section{Pandemi Covid-19}

Menghadapi Pandemi COVID-19 ini, pemerintah menerapkan kebijakan Pembatasan Sosial Berskala Besar (PSBB) di beberapa daerah. Kebijakan tersebut akhirnya membatasi aktivitas social ekonomi masyarakat seperti transportasi, pusat perbelanjaan, tempat rekreasi dan hiburan menjadi tertutup. Keadaan ini sangat berdampak terhadap kondisi social ekonomi masyarakat sehubungan dengan pekerjaan, kegiatan industri, maupun kegiatan UMKM.

Pemerintah memberlakukan social distancing, phycial distancing dan lockdown untuk membatasi ruang gerak masyarakat. Tujuan pemerintah menerapkan kebijakan tersebut agar dapat menghambat penularan Virus Corona. Kebijakan Lockdown ini menghentikan aktivitas masyarakat di luar rumah bahkan mereka yang bekerja harian atau pedagang kaki lima. Banyak pihak yang merasakan dampak dari pandemi ini, seperti pegurangan jam kerja, pendapatan masyarakat berkurang, terutama buruh dengan penghasilan harian, pelaku usaha, ojek online dan lainnya sebagainya.

\section{METODE PENELITIAN}

\section{Jenis Penelitian}

Penelitian ini menggunakan metode penelitian kualitatif dengan pendekatan fenomenologi. Sumber data dalam penelitian menggunakan data primer dan sekunder. Data primer dalam penelitian ini yaitu hasil dari wawancara daring dengan beberapa mahasiswa Program Studi Manajemen melalui aplikasi Google Meet. Sedangkan data sekunder merupakan data yang didapat dari berbagai literasi seperti buku, artikel, jurnal, dan lain sebagainya. 


\section{Tempat Penelitian}

Penelitian ini dilakukan secara online untuk menghambat proses penyebaran virus Corona.

\section{Populasi dan Sampel}

Populasi dalam penelitian ini yaitu mahasiswa Program Studi Manajemen angkatan 2018. Teknik pengambilan sampel dalam penelitian ini adalah teknik purposive sampling, yaitu teknik pengambilan sumber data dengan pertimbangan tertentu. Sampel yang digunakan yaitu sebanyak 26 narasumber.

\section{Teknik Pengumpulan Data}

Teknik pengumpulan data yang digunakan dalam penelitian ini melalui wawancara dengan narasumber dari mahasiswa Program Studi Manajemen UIN Sunan Ampel Surabaya angkatan 2018.

\section{Teknik Analisis Data}

Teknik analisis data dalam penelitian ini menggunakan analisis model Miles and Huberman. Miles and Huberman (1984) mengemukakan bahwa aktivitas dalam analisis data kualitatif dilakukan secara interaktif dan berlangsung secara terus-menerus sampai tuntas, sehingga datanya sudah jenuh[9]. Aktivitas dalam analisis data ini yaitu meliputi pengumpulan data, reduksi data, penyajian data dan kesimpulan.

\section{HASIL DAN PEMBAHASAN}

Pandemi Covid-19 merupakan musibah yang sangat memprihatinkan untuk seluruh manusia. Pandemi Covid-19 menyebabkan beberapa perusahaan untuk memulangkan sebagian besar karyawan. Begitu juga para pelaku usaha, tidak banyak dari mereka merasa bahwa pandemi Covid-19 ini menjadi momok tersendiri.

\section{Karakteristik Responden}

Responden dalam penelitian ini ialah mahasiswa Program Studi Manajemen angkatan 2018 yang pernah bekerja dan berwirausaha. Penelitian ini di mulai dari menentukan responden dengan menggunakan teknik purposive sampling dengan mempertimbangkan beberapa hal berikut:

1) Mahasiswa program studi manajemen yang pernah bekerja, baik part time maupun full time.

2) Mahasiswa program studi manajemen yang pernah melakukan kegiatan berwirausaha.

3) Mahasiswa program studi manajemen yang pernah bekerja dan berwirausaha.

\section{Reduksi Data}

Reduksi data merupakan proses pemilihan, pemusatan perhatian pada penyederhanaan dan transformasi data "kasar" yang muncul dari catatan di lapangan. Telah ditemukan beberapa data atau pertanyaan yang berkaitan dengan minat berwirausaha di masa Pandemi Covid-19 sebagai berikut.

1. Alasan minat berwirausaha (P1)

2. Apakah terdapat tuntutan dari orang terdekat (P2)

Serta terdapat beberapa pertanyaan yang berkaitan dengan minat bekerja sebagai karyawan di masa Pandemi Covid-19 yakni sebagai berikut:

1. Alasan minat bekerja sebagai kayawan (P3)

2. Apakah terdapat tuntutan dari orang terdekat (P4)

Berbagai data yang telah didapat, kemudian dimasukkan dalam tahap berikutnya yaitu penyajian data dan penarikan kesimpulan atau verifikasi. Pada penelitian ini, peneliti menggunakan penyajian deskriptif analitis untuk data hasil wawancara dan observasi. Seluruh responden telah bersedia untuk memberikan data yang berkaitan dengan berbagai hal diatas. Hasil tanggapan responden terhadap seluruh pertanyaan dapat dilihat pada tabel dibawah ini.

Tabel 3.1 Tanggapan responden mengenai P1

\begin{tabular}{c|l|c}
\hline No & Alasan minat berwirausaha & Jumlah \\
\hline 1 & Mengembangkan potensi diri & 2 \\
\hline
\end{tabular}




\begin{tabular}{c|l|c}
\hline 2 & $\begin{array}{l}\text { Mengimplementasikan ilmu } \\
\text { kewirausahaan }\end{array}$ & 3 \\
\hline 3 & $\begin{array}{l}\text { Ingin membuka lapangan } \\
\text { pekerjaan }\end{array}$ & 6 \\
\hline 4 & $\begin{array}{l}\text { Ingin bebas mengelola } \\
\text { pekerjaannya sendiri }\end{array}$ & 5 \\
\hline 5 & Melanjutkan usaha keluarga & 1 \\
\hline \multicolumn{2}{r}{ Jumlah } & 17 \\
\hline
\end{tabular}

Bedasarkan tabel 3.1 diatas, dapat diketahui bahwa tanggapan responden mengenai alasan minat berwirausaha di masa Pandemi Covid-19 didominasi karena responden ingin membuka lapangan pekerjaan baru. Karena dimasa pandemi seperti ini banyak sekali perusahaan-perusahaan yang mengurangi jumlah pegawainya. Dengan begitu, menciptakan lapangan pekerjaan merupakan solusi yang baik dalam mengatasi permasalahan minimnya lapangan pekerjaan.

Tabel 3.2 Tanggapan responden mengenai P2

\begin{tabular}{c|l|c}
\hline No & $\begin{array}{l}\text { Adanya tuntutan dari } \\
\text { lingkungan sekitar }\end{array}$ & Jumlah \\
\hline 1 & Tidak ada tuntutan & 13 \\
\hline 2 & $\begin{array}{l}\text { Terdapat tuntutan dari orang } \\
\text { sekitar }\end{array}$ & 4 \\
\hline \multicolumn{2}{r}{ Jumlah } & 17 \\
\hline
\end{tabular}

Bedasarkan data diatas, dapat diketahui bahwa sebanyak 13 responden tidak mendapat tuntutan dari lingkungan terdekatnya mengenai berwirausaha di masa Pandemic Covid-19. Sedangkan sebanyak 4 responden mengatakan bahwa berwirausaha merupakan tuntutan dari keluarga. Mereka dituntut para orang tuanya untuk melanjutkan bisnis yang telah dibangun sebelumnya.

Tabel 3.3 Tanggapan responden mengenai P3

\begin{tabular}{clc}
\hline No & Alasan minat bekerja & Jumlah \\
\hline 1 & Penghasilan pasti & 5 \\
\hline 2 & Meminimalisir resiko & 1 \\
\hline 3 & Menambah pengalaman & 1 \\
\hline 4 & $\begin{array}{l}\text { Mencari modal untuk } \\
\text { melanjutkan berwirausaha }\end{array}$ & 2 \\
\hline \multicolumn{2}{c}{ Jumlah } & 9 \\
\hline
\end{tabular}

Berdasarkan table 3.1 diatas, dapat disimpulkan bahwa alasan responden memilih minat bekerja sebagai karyawan di masa Pandemi Covid-19 didominasi karena ingin mendapatkan penghasilan tetap setiap bulannya. Hal tersebut dikarenakan dengan adanya penghasilan tetap maka perekonomian seseorang akan lebih terjamin apalagi di masa pandemi Covid-19 ini.

Tabel 3.4 Tanggapan Responden mengenai P4

\begin{tabular}{l|l|c}
\hline No & $\begin{array}{l}\text { Adanya tuntutan dari } \\
\text { lingkungan sekitar }\end{array}$ & Jumlah \\
\hline 1 & Tidak ada tuntutan & 9 \\
\hline 2 & $\begin{array}{l}\text { Terdapat tuntutan dari orang } \\
\text { sekitar }\end{array}$ & - \\
\hline \multicolumn{2}{r}{ Jumlah } & 9 \\
\hline
\end{tabular}

Bedasarkan data diatas, dapat diketahui bahwa seluruh responden menjawab tidak ada tuntutan dari lingkungan sekitar mereka untuk bekerja sebagai karyawan di masa Pandemi Covid-19. Mereka murni ingin bekerja sebagai karyawan karena keinginanpribadi, serta profesi yang ada didalam lingkungan sekitarnya didominasi oleh seorang karyawan.

\section{Minat Berwirausaha di Masa Pandemi Covid-19}

Menurut Edi Supriyanto (2020), seorang pengusaha bukan hanya tentang seorang yang pemberani, tetapi juga harus mempunyai sesuatu yang bersifat inovatif dan kreatif. Wirausaha adalah bentuk usaha mandiri yang mengolah usahanya serta pekerjanya adalah diri sendiri serta. Dalam wirausaha dua unsur pokok yang senantiasa penting, yaitu peluang dan cara menggapai peluang. Bagi seorang entrepreneur, peluang akan menjadi kesempatan yang dimulai dari kesempatan kecil sampai akhirnya jadi pengusaha besar.

Berdasarkan teori tersebut dapat diketahui bahwa menjadi seorang pengusaha harus memiliki jiwa yang kreatif dan inovatif agar dapat menggapai peluang untuk menjadi pengusaha besar yang dikenal oleh masyarakat. Dengan adanya kreativitas dan inovasi dapat 
membuat sesuatu yang diciptakan berbeda dengan yang lain dan dapat menarik konsumen.

Hadirnya seorang wirausahawan ditengah masyarakat sangat bermanfaat apalagi di kondisi pandemi Covid-19. Dengan berwirausaha dapat membuka lowongan atau kesempatan lapangan pekerjaan baru bagi masyarakat sekitar, sehingga dapat membantu mengurangi tingkat pengangguran.

Dari hasil survey dengan beberapa mahasiswa, alasan responden lebih memilih minat berwirausaha di masa pandemic Covid-19 adalah karena dimasa pandemi Covid-19 seperti ini, banyak perusahaan-perusahaan yang mengurangi jumlah pegawainya, jadi sulit jika harus mencari pekerjaan. Dengan berwirausaha mereka dapat membuka lapangan pekerjaan baru untuk orang-orang yang terkena dampak pandemic Covid-19. Responden juga ingin mengimplementasikan ilmu kewirausahaan yang telah dipelajari dimasa kuliah untuk diterapkan setelah lulus kuliah. Serta menjadi seorang pengusaha, kegiatan berwirausaha ini dapat mengembangkan kemampuan dan potensi diri dalam mengelola keuangan yang jauh lebih baik lagi ketimbang harus menjadi karyawan pada pandemi saat ini.

\section{Minat Bekerja sebagai Karyawan di Masa Pandemi}

Minat kerja menurut Walgito (2008) dalam penelitian yang berjudul "Pengaruh Efikasi Diri, Minat Kerja, dan Bimbingan Karir Terhadap Kesiapan Kerja Siswa Kelas Xi Program Keahlian Akuntansi SMKN 1 Kendal" yaitu apabila seseorang telah mempunyai informasi dan pengetahuan mengenai suatu pekerjaan yang diminati maka seseorang tersebut akan cenderung berupaya mempersiapkan diri secara matang untuk mencapai suatu pekerjaan [10].

Berdasarkan teori tersebut dapat diketahui bahwa menjadi karyawan perlu mempersiapkan diri untuk memasuki dunia kerja. Beberapa hal yang harus disiapkan yaitu salah satunya skill. Tanpa skill yang memadai maka akan sulit untuk menyesuaikan diri di dunia kerja.

Dari hasil wawancara, mahasiswa yang memilih minat bekerja sebagai karyawan, mereka menginginkan setelah mendapatkan pengalaman kerja di dunia kerja, mereka baru akan mencoba untuk memulai berwirausaha. Karena dengan mendapatkan pengalaman di dunia kerja, dapat menjadikan patokan dalam membuat usaha. Serta penghasilan menjadi seorang karyawan juga lebih terjamin di masa pandemi dengan perekonomian yang tidak menentu ini.

Mereka juga menyampaikan bahwa merintis suatu usaha di masa pandemi Covid-19 bukanlah hal yang mudah, terlebih banyak yang belum memiliki cukup modal untuk dapat berwirausaha. Modal untuk berwirausaha menjadi poin utama yang banyak dikeluhkan para narasumber. Oleh karena itu, bekerja sebagai karyawan adalah keputusan yang baik untuk melanjutkan kehidupan setelah kuliah.

\section{Perbandingan Minat Berwirausaha dan Bekerja Sebagai Karyawan di Masa Pandemi Covid-19}

Menjadi pengusaha atau karyawan merupakan pilihan profesi yang paling diminati banyak orang. Meskipun demikian, kedua profesi tersebut memiliki kelebihan dan kelemahan masing-masing.

Menurut Buchari Alma (2011), terdapat beberapa kelebihan menjadi wirausahawan, yaitu, 1) Mencapai tujuan yang dikehendaki sendiri; 2) Mendemonstrasikan potensi seseorang secara penuh; 3) Memperoleh manfaat dan keuntungan akan kering maksimal. 4) Membantu masyarakat dengan usaha-usaba konkret; 5) Menjadi bos minimal bagi dirinya sendiri. Sedangkan kelemahan menjadi wirausahawan yaitu, 1) Memperoleh pendapatan yang tidak pasti dengan memikul berbagai risiko; 2) Bekerja keras dan atau jam kerja yang mungkin lebih panjang; 3) Kualitas hidup mungkin masih Rendah sampai usahanya berhasil; 4) Memiliki tanggung jawab sangat besar, banyak keputusan 
yang harus dibuat walaupun mungkin kurang menguasai permasalahan yang dihadapinya [11]. Menjadi karyawan juga memiliki kelebihan dan kelemahan. Menurut Suparyanto (2006) kelebihannya diantara lain yaitu, 1) Memiliki jam keja yang pasti; 2) tanggung jawab terbatas dan beresiko rendah 3) penghasilan relative pasti setiap bulannya. Sedangkan kelemahan bekerja sebagai karyawan yaitu, 1) Harus rela diperintah; 2) Bertanggung-jawab kepada atasan; 3) Sukar untuk menyampaikan ide karena terkadang banyak atasan yang sering mengabaikan ide dari bawahan.

Berdasarkan hasil wawancara dengan responden, terdapat perbandingan antara minat berwirausaha dan bekerja sebagai karyawan. Perbandingan antara minat berwirausaha dan minat bekerja sebagai karyawan dapat dilihat dari hasil minat berwirausaha berwirausaha lebih unggul yaitu sebanyak 17 responden dari 26 responden dan sisanya sebanyak sebanyak 9 responden lebih memilih untuk bekerja sebagai karyawan di masa Pandemi Covid-19. Beberapa responden mengatakan bahwa alasan utama mereka memilih minat berwirausaha karena dengan berwirausaha seseorang dapat bermanfaat untuk masyarakat karena dapat memberikan lapangan pekerjaan dalam kondisi yang minim untuk perusahaan menerima karyawan di masa pandemi Covid-19.

Berdasarkan teori diatas dengan hasil wawancara terdapat kesesuaian yaitu terletak pada kelebihan dari minat berwirausaha. Dapat diketahui bahwa minat berwirausaha dapat mendemonstrasikan potensi seseorang secara penuh. Hasil wawancara dengan responden juga mengungkap bahwa dengan berwirausaha, seseorang dapat mengembangkan potensi atau skill yang dimilikinya. Begitu juga dengan kelebihan dari minat bekerja sebagai karyawan, yaitu memiliki penghasilan yang pasti setiap bulannya. Hasil wawancara dengan responden mengungkap bahwa dengan bekerja sebagai karyawan dapat memiliki penghasilan tetap meskipun penghasilannya tidak banyak.

\section{KESIMPULAN}

Bedasarkan hasil penelitian dan analisis data diatas, dapat ditarik kesimpulan bahwa:

1. Minat berwirausaha di masa pandemi Covid-19 pada mahasiswa Program Studi Manajemen tergolong lebih tinggi yaitu sebanyak 17 responden dibanding minat bekerja sebagai karyawan di masa pandemi Covid-19 yakni sebanyak 9 responden.

2. Alasan responden memilih minat berwirausaha karena di masa pandemi Covid-19 ini banyak perusahaan yang mengurangi jumlah kayawannya atau memutuskan hubungan kerja. Dengan berwirausaha, mereka akan membuka lapangan pekerjaan baru untuk orang-orang yang terkena dampak Covid-19. Serta mereka juga ingin bebas dalam mengelola pekerjaannya sendiri.

3. Alasan responden memilih minat bekerja sebagai karyawan yaitu karena dengan bekerja sebagai karyawan mereka akan mendapatkan penghasilan tetap setiap bulannya. Meskipun di masa pandemic Covid-19 ini banyak perusahaan atau instansi yang mengurangi jumlah karyawannya, para responden akan tetap kukuh pada pendiriannya dan akan lebih giat dalam mempersiapkan diri untuk bersaing dalam dunia kerja.

\section{Daftar Pustaka}

[1] K. K. Indonesia, "STATISTIK," vol. 19, no. 86, pp. 1-24, 2020.

[2] A. F. Thaha, "Dampak Covid-19 Terhadap UMKM di Indonesia," $J$. Brand, vol. 2, no. 1, pp. 147-153, 2020.

[3] A. Adi, "Analisis penyebab tingginya pengangguran sarjana di kecamatan simeulue barat kabupaten simeulue," pp. 1-40, 2016.

[4] S. E. ,M. . Sayu Ketut Sutrisna Dewi, "Konsep Dan Pengembangan Kewirausahaan Di Indonesia - Sayu Ketut Sutrisna Dewi - Google Buku," Cv Budi 
Utama. pp. 1-108, 2017,

[5] E. B. M. E. B. Madya, "Pentingnya Pembinaan Sumber Daya Manusia Dalam Organisasi Dakwah," Al-Idarah J. Pengkaj. Dakwah dan Manaj., vol. 5, no. 6, pp. 1-12, 2018.

[6] M. Ikramullah, A. Aslinda, and $\mathrm{H}$. Heriansah, "Faktor Determinan Minat Berwirausaha Mahasiswa (Evaluasi Pembelajaran Kewirausahaan Di Perguruan Tinggi Perikanan Dan Kelautan)," J. Kewirausahaan dan Bisnis, vol. 25, no. 2, p. 59, 2020, doi: 10.20961/jkb.v25i2.44990.

[7] Y. Pratiwi and I. Wardana, "Pengaruh Faktor Internal Dan Eksternal Terhadap Minat Berwirausaha Mahasiswa Fakultas Ekonomi Dan Bisnis Universitas Udayana," None, vol. 5, no. 8, p. 247274, 2016.

[8] P. Reputasi, D. A. N. L. Kerja, K. D. Permadi, I. G. Salit, and K. Netra,
"UNIVERSITAS UDAYANA Fakultas Ekonomi dan Bisnis Universitas Udayana , Bali , Indonesia Fakultas Ekonomi dan Bisnis Universitas Udayana , Bali , Indonesia," vol. 4, no. 10, pp. 3256-3286, 2015.

[9] Sugiono, Metode Penelitian Kuantitatif, Kualitatif, dan $R \& D$. Bandung: Penerbit Alfabeta, 2016.

[10] N. Ngadi, R. Meliana, and Y. A. Purba, "Dampak Pandemi Covid-19 Terhadap Phk Dan Pendapatan Pekerja Di Indonesia," J. Kependud. Indones., vol. 2902, p. 43, 2020, doi: 10.14203/jki.v0i0.576.

[11] M. Sabyan Echdar, Business Ethics And Entrepreneurship: Etika Bisnis Dan Kewirausahaan. Yogyakarta: Deepublish, 2019. 